\title{
An Empirical Study on the Influencing Factors of Premium Income Level of Family Property Insurance in China
}

\author{
Jiahui Wang, Qian Guo \\ Department of Statistics, Beijing Wuzi University, Beijing, China \\ Email address: \\ 1501299289@qq.com (Jiahui Wang) \\ To cite this article: \\ Jiahui Wang, Qian Guo. An Empirical Study on the Influencing Factors of Premium Income Level of Family Property Insurance in China. \\ Journal of World Economic Research. Vol. 6, No. 5, 2017, pp. 67-70. doi: 10.11648/j.jwer.20170605.12
}

Received: November 6, 2017; Accepted: November 27, 2017; Published: January 2, 2018

\begin{abstract}
Based on the data of China's property insurance premiums from 1998 to 2015, this paper from the six aspects of production, consumption, income, investment, inflation and resident insurance awareness. including the gross domestic product (GDP), premium income of property and casualty insurance Consumption levels, consumer price index (base period), general college and above graduates, the entire social housing investment and urban and rural residents disposable income seven macro indicators of China's home insurance premium income conducted a multiple regression analysis.
\end{abstract}

Keywords: Household Property Insurance, Multiple Regression, Stepwise Regression, Household Consumption

\section{Research Background and Purpose}

The development of China's family property insurance is not optimistic. The most prominent place is the problem of low insurance rate, as well as the product structure is single, the scope of protection is not wide enough, product differentiation is low and sales channels are not appropriate and people's risk awareness is weak and so on.

Family property insurance is very benefit for us, through the family property insurance plan, Scholar can transform unexpected disasters and accidents into small amount and fixed premium expenditure to ensure the stability of family financial affairs. Based on the above description, in order to promote the China family property insurance system more perfect, the insurance products to better meet the needs of the people, to better serve the human society, the study of family property insurance is very necessary.

\section{Research and Review of Family Property Insurance in China}

China's family property insurance has a long history, after the resumption of insurance business in 1980, the family property insurance business has been going on, which is one of the categories developed earlier and faster, broader coverage of business in China.
Wang Jun (2012) [1] put forward the current problems of China's property insurance at the "Research on Family Property Insurance in our country". Insufficient insufficient rates, insufficient attention, low product differentiation, lack of suitable sales channels, and ancillary services Perfect and so on. In addition, he also made an empirical analysis of the factors that affect China's family property insurance. The empirical analysis shows that the per capita disposable income of urban residents and the premium income of the previous year are positively related to the premium income of the family property insurance. However, the total GDP contradicts the previous theoretical analysis and shows a negative correlation; Education expenditure, consumer price index and the entire social housing investment did not pass the test.

Li Ying (2013) [2] described the current situation of China's family property insurance, the reasons for the insured rate of China's family property insurance, and the strategy analysis of promoting the development of China's family property insurance in the article "The Status Quo and Development Strategy of Chinese Family Property Insurance". Li Ying believes that the development of China's property insurance industry is characterized by large business diversification, a small amount of large, high cost, risk structure, unique risk management, high level of insurance.

Zhang Fu Shuang (2016) [3] also mentioned in the "Analysis of the Problems and Solutions to Family Property Insurance" that the existing problems of family property 
insurance in China are mainly the low overall quality of insurance practitioners, the single product structure, the inadequate publicity, Insurance supporting services is not enough and so on. The solution is to improve the overall quality of employees, and actively carry out insurance product innovation, improve the promotion of efforts and service innovation to improve the viscosity. Xu Chun hong (2013) [4] also described the existing problems of Chinese property insurance and its development counter measures in the article "The Status Quo and Development of Chinese Home Property Insurance." Apart from the above, she also pointed out that Chinese insurance companies should pay attention to the management of home insurance And the implementation of differentiated marketing strategies and other measures.

To sum up, there are also a few studies on Chinese property insurance by Chinese scholars. Most of the articles are about descriptive analysis of the current situation and development strategies of property insurance in China. According to the findings of previous scholars, the development prospects of property insurance in China should have been very successful, but its development is very unsatisfactory. The main reasons are: First, There is a single product structure, innovation is not enough; Second, marketing strategies need to be improved; Third, the overall quality of insurance practitioners need to be improved; Fourth, the publicity is not enough. Based on the above description, empirical analysis of the main macroeconomic factors that affect its premium income is still lacking [5]. Based on the previous scholars 'research, this paper mainly studies seven macroeconomic indicators, namely, GDP, premium income of property insurance, residents' consumption level, consumer price index (base period), general college and above graduates, the whole society Residential investment and urban-rural residents disposable income regression analysis.

\section{Establishment of Index System}

In this paper, the indicators are mainly selected from the aspects of production, consumption, income, investment, inflation and insurance awareness to analyze the influence of family property insurance premium income from as many aspects as possible.

\subsection{Index Selection}

In terms of production, choosing the indicator of GDP, GDP is the most direct manifestation of a country's economic development level, and it is also the best choice to reflect the impact of production on the premium income of property insurance. In terms of consumption, Residents consumption level of this indicator, consumer spending constitutes an important part of consumption, it has a certain impact on the insurance premiums of home insurance; income, the choice of disposable income urban and rural residents of this indicator, the demand for property insurance is not Only urban residents and rural residents at the same time, the indicators of the data is through urban residents and rural residents disposable income sum up; in investment, the choice of social housing investment this indicator, residential and home insurance are closely linked, This indicator can best reflect the impact of investment on the demand for home insurance; In terms of inflation, the index of consumer price index is selected, which reflects the change of price level of consumer goods and services generally purchased by households. In terms of insurance awareness, Chose the property and casualty insurance premium income and the number of regular college graduates and above two Indicators, because the residents of a sense of insurance is a relatively abstract concept, where scholars do not have specific data, this paper uses China's nearly 18 years of property insurance premium income data as a reflection of the Chinese residents on the insurance property insurance sense of a reflection; While the number of regular college graduates and above is to reflect the impact of China's education level on the demand for family property insurance [6].

\subsection{Data Sources}

In this chapter, the data of GDP, the consumption level of residents, property insurance premium income, resident consumption price index, urban and rural residents disposable income, college graduates and above, the number of residential investment of whole society and family property insurance premium income comes from the People's Republic of China National Bureau of statistics and statistical yearbook China website, this paper makes regression analysis using 1998-2015 data [7], the analysis results is Eviews 7.2 software.

\section{Model Establishment and Inspection}

This section builds an economic model of home insurance premiums and makes a preliminary multivariate regression analysis. The results show that the level of residents' consumption, total social housing investment and resident disposable income are not significant under the condition of $\alpha$ $=0.05$.

In order to better grasp the development trend of home insurance premium income, at the same time to study the impact of these seven factors on home insurance premium income, here Scholars can establish the following economic model:

$$
Y_{i}=\beta_{0}+\beta_{1} X_{1}+\beta_{2} X_{2}+\beta_{3} X_{3}+\beta_{4} X_{4}+\beta_{5} X_{5}+\beta_{6} X_{6}+\beta_{7} X_{7}+\mu_{i}
$$

In the formula, $Y_{i}$ is the property insurance premium income; $X_{1}$ is insurance premium income; $X_{2}$ is the gross domestic product (GDP) for the residents; $X_{3}$ is consumption level; $X_{4}$ is ordinary college graduates and above; $X_{5}$ is residential investment of whole society; $X_{6}$ is the residents' disposable income; $\mathrm{X}_{7}$ is consumer price index; $\mu_{\mathrm{i}}$ is random error term.

Under the condition of $\alpha=0.05$, the final remaining three variables were tested, namely, gross domestic product, the 
number of college graduates and above, and the consumer price index. We next to the model of stepwise regression,

stepwise elimination of some independent variables. The results of stepwise regression are shown in the following table.

Table 1. Regression results after stepwise elimination.

\begin{tabular}{llll}
\hline Variable & Coefficient & Std. Error & t-Statistic \\
\hline C & 143.2995 & 55.73664 & 2.571010 \\
X2 & 0.000187 & $3.94 \mathrm{E}-05$ & 4.736723 \\
X4 & -0.039673 & 0.011070 & -3.583959 \\
X7 & -0.326539 & 0.138919 & -2.350578 \\
R-squared & 0.914273 & Mean dependent var & 0.0003 \\
Adjusted R-squared & 0.895903 & S. D. dependent var & 0.0030 \\
S. E. of regression & 3.028018 & Akaike info criterion & 0.0339 \\
Sum squared resid & 128.3645 & Schwarz criterion & 20.40167 \\
Log likelihood & -43.22141 & Hannan-Quinn criter. & 9.385115 \\
F-statistic & 49.76981 & Durbin-Watson stat & 5.246824 \\
Prob (F-statistic) & 0.000000 & & 5.444684 \\
\hline
\end{tabular}

According to the data in the Table 1, the model can be written as:

$$
\widehat{Y}_{i}=143.2995+0.000187 X_{2}-0.039673 X_{4}-0.326539 X_{7}
$$

From the data of Table 1, Scholars can get that: the correction coefficient of the correction is 0,895903 , which shows that the model fits well to the sample, the three explanatory variables are correct for the explanatory variable --- China's property insurance premium income Most differences make explanations. At the same time, it can be seen that $F=49.76981>(2,15)$, which shows that the regression equation is significant, that is, the GDP, collage graduations and above and the consumer price index and other variables together do have the property insurance premium income Significant impact. After excluding several factors, the $P$ values are less than 0.05 , indicating that at the significant level of $\mathrm{a}=0.05$, three factors, $\mathrm{X} 2, \mathrm{X} 4$ and $\mathrm{X} 7$, have a significant impact on home insurance premiums.

\section{Conclusion}

Through the test of the GDP, the coefficient is 0.000187 , indicating that the demand for property insurance is directly proportional to the indicator. This shows that the country's level of economic development has a leading role in the demand for family property insurance. The more the economy develops, the more diverse the people's needs. As a result, the residents' demand for house property insurance also increases [8].

The number of regular college graduates and above passed the test with a coefficient of -0.039673 , indicating that the indicator's demand for family property insurance is negatively correlated, which is contrary to our original assumption. This also shows that with the improvement of education, people with a high level of education also have higher risk awareness and risk sensitivity.

The consumer price index through the test, the coefficient of -0.326539 , indicating the index on the demand for personal property insurance was significantly negatively correlated. This shows that the higher the inflation rate, the lower the actual income of residents, and thus the less demand for property insurance.

In the model of this paper, the residents' consumption level, the premium income of property insurance, the investment of social housing and the disposable income of residents failed to pass the test in this model, and the change in premium income of property insurance is not significant. This result runs counter to the original hypothesis, and needs more in-depth research to explore the impact of these indicators on the property insurance, in this article will not repeat them [9].

To sum up, in order to increase the premium income of China's property insurance, at the national level, it is to enhance the country's level of economic development, improve China's GDP, thereby promoting the demand for home insurance [9]; on the market level, inflation restrains the property insurance At the individual level, although the indicators of residents' sense of insurance coverage in this model have not passed the test, they have raised their awareness of insurance coverage and improved the insurance policies for residents Attitude for the development of family property insurance is extremely effective.

\section{References}

[1] Wang Jun. China's Family Property Insurance Study [J]. Business Economics, 2012.

[2] Li Ying. China's family property insurance status and development strategy [J]. 2013.

[3] Zhang Fushuang. Problems existing in family property insurance and countermeasures $[\mathrm{J}]$. Production Economics, 2016, (22).

[4] Xu Chunhong. Current situation and development of family property insurance in China [J]. Financial Window, 2013, 12 [2017-05-08].

[5] Jia Jun. On China's family property insurance development [J/ OL]. Business Economics, 2011, 1 [2017-05-07].

[6] National Bureau of Statistics of China Statistical Yearbook -2016 [M]. Beijing: China Statistics Press, 2016.

[7] Wang and. China's family property insurance research [J]. Insurance Research, 2008 (3): 34. 
[8] SUN Suying. Current situation and countermeasures of family property insurance in China [ $\mathrm{J} / \mathrm{OL}]$. Management Observation, 2014, [2017-05-08].
[9] $\mathrm{Xu}$ Chunhong, $\mathrm{Lu}$ Zhengnan. Current situation and development of family property insurance in China [J]. Special Economic Zone, 2014 (2). 